\title{
Use of seasonal trend decomposition to understand groundwater behaviour in the Permo-Triassic Sandstone aquifer, Eden Valley, UK
}

\author{
Antoine E. A. Lafare ${ }^{1}$ - Denis W. Peach ${ }^{1}$ - Andrew G. Hughes ${ }^{1}$ \\ Received: 16 February 2015 / Accepted: 17 August 2015 / Published online: 16 October 2015 \\ (C) The Author(s) 2015. This article is published with open access at Springerlink.com
}

\begin{abstract}
The daily groundwater level (GWL) response in the Permo-Triassic Sandstone aquifers in the Eden Valley, England (UK), has been studied using the seasonal trend decomposition by LOESS (STL) technique. The hydrographs from 18 boreholes in the Permo-Triassic Sandstone were decomposed into three components: seasonality, general trend and remainder. The decomposition was analysed first visually, then using tools involving a variance ratio, time-series hierarchical clustering and correlation analysis. Differences and similarities in decomposition pattern were explained using the physical and hydrogeological information associated with each borehole. The Penrith Sandstone exhibits vertical and horizontal heterogeneity, whereas the more homogeneous St Bees Sandstone groundwater hydrographs characterize a wellidentified seasonality; however, exceptions can be identified. A stronger trend component is obtained in the silicified parts of the northern Penrith Sandstone, while the southern Penrith, containing Brockram (breccias) Formation, shows a greater relative variability of the seasonal component. Other boreholes drilled as shallow/deep pairs show differences in responses, revealing the potential vertical heterogeneities within the Penrith Sandstone. The differences in bedrock characteristics between and within the Penrith and St Bees Sandstone formations appear to influence the GWL response. The deseasonalized and de-trended GWL time series were then used to characterize the response, for example in terms of memory effect (autocorrelation analysis). By applying the STL method, it is possible to analyse GWL hydrographs leading to better conceptual understanding of the groundwater flow.
\end{abstract}

Antoine E. A. Lafare

antoinel@bgs.ac.uk; antoine.lafare@laposte.net

1 British Geological Survey, Nottingham NG12 5GG, UK
Thus, variation in groundwater response can be used to gain insight into the aquifer physical properties and understand differences in groundwater behaviour.

Keywords UK · Groundwater statistics · Time series analysis $\cdot$ Sandstone $\cdot$ Conceptual models

\section{Introduction and previous work}

Catchments very often exhibit high levels of heterogeneity and complexity, which impact on their surface and groundwater hydrology (e.g. Di Lazzaro et al. 2015). In order to effectively manage water resources and flood risk, it is necessary to adequately understand the processes that control the functioning of these systems. To develop an understanding of the hydrology of catchments, different approaches can be taken, but these normally involve a combination of data gathering and monitoring as well as the interpretation of that data to develop a conceptual understanding and the subsequent mathematical modelling of the hydrological system. This sequence of activity leads, ideally, to the ability to make forecasts or predictions of future behaviour under differing conditions. Observed data collected within a catchment such as groundwater levels or stream flows, represent information essential to understanding the hydrological system. These variables are usually measured sequentially in time, and when observations are collected over a fixed sampling interval they form a historical time series (Metcalfe and Cowpertwait 2009), allowing the investigation of temporal behaviour. From a statistical point of view, such historical time series can be treated as realisations of sequences of random variables that can be described by time-series analysis. A groundwater system can be viewed as a filter transforming an input signal (such as rainfall) into an output signal (e.g. flow or groundwater level) by 
application of a transfer function (e.g. Delbart et al. 2014). Once defined, these mathematical relationships can be interpreted to help determine the functioning, organisation and structure of aquifers. There are a number of time-series techniques that have been commonly used to characterize groundwater systems, with a range of functions (extensively described by Box et al. 2008) that can be interpreted from a hydrogeological perspective. Two of the most commonly used techniques in hydrology to undertake this analysis are autocorrelation, which enables the quantification of memory effects in a groundwater system (e.g. Larocque et al. 1998), and cross correlation, the latter representing the inter-relationship between input and output time series (e.g. Chae et al. 2010). Bloomfield and Marchant (2013) use the autocorrelation of a standardised groundwater level Index (SGI) time series to infer dominant aquifer flow and storage characteristics of various aquifers in the UK.

Nevertheless, autocorrelation and cross-correlation are rarely directly employed to describe groundwater level evolution in boreholes. This is mostly due to the high inertia and long time-scales needed to see changes that are exhibited by groundwater systems (Lee and Lee 2000; Rademacher et al. 2002) and the continuous nature of the groundwater level change which is particularly important in inter-granular aquifers. These techniques have, therefore, mainly been employed in groundwater systems with higher frequency variations, like those dominated by fracture flow. Thus, to better understand the groundwater flow in a catchment dominated by intergranular flow a different methodology is needed.

A hydrological time series and particularly a groundwaterlevel time series can be regarded as an additive time series (Metcalfe and Cowpertwait 2009). Therefore, it can be decomposed into different components that should be able to be related to different processes acting in the generation of the time series. In this case, groundwater-level time series was decomposed in three components:

1. Trend component representing the long-term processes that operate over the time period spanned by the series. Depending on the temporal scaling, it can also contain abrupt system-related changes. In the case of a groundwater system, it can be influenced by mid- to long-term climatic oscillation.

2. Seasonal or repeated component representing a cyclical process (in the case of a groundwater system the annual fluctuations resulting from a recharge season). Cyclic processes over a longer period can also occur in groundwater dynamics such as the 7-year El Nino effect; however, the data set presented in this report spans only 12 years, and longer period cyclic processes are more likely to be picked up by the trend component.

3. Remainder, residual or noise component, obtained by removing the trend and the seasonal component from the original signal. This is likely to represent local processes which cause variability between cycles and can thus be related to shorter-term events or impacts on the groundwater system. Other variability such as measurement issues and unexplainable white noise can be included as well in this remaining component; however, white noise is likely to be less important for groundwater level fluctuations than for, e.g. rainfall time series.

An observed groundwater-level time series represents the response of an aquifer to the rainfall recharge and other impacts on the groundwater flow regime, like groundwater/ surface-water interactions and abstractions. A seasonal trend decomposition such as the seasonal decomposition of time series by LOESS (STL; Cleveland et al. 1990) can help to characterize this response, allowing the identification of similar and differing shape and variability components between one borehole and another (Taylor and Alley 2002).

The removal of the trend takes away most of the autocorrelation due to the continuous nature of groundwater level change, especially in granular aquifers such as the PermoTriassic Sandstone described in this report. The subsequent removal of the cycle/seasonal component takes away any autocorrelation due to seasonality. The remainder of the signal is therefore more likely to represent localized responses to hydrological extreme events.

The STL technique is generally considered as a mainly exploratory or descriptive tool (Taylor and Alley 2002); nevertheless, it has been successfully used to reveal structure in environmental time series in various domains: water quality (Esterby 1993), ecology (Chaloupka 2001; Balazs and Chaloupka 2004), atmospheric science (Carslaw 2005) and groundwater levels (Shamsudduha et al. 2009).

Once the characteristics of the borehole response have been derived, it is possible to define clusters within groundwaterlevel data sets to determine groups of boreholes characterized by a similar behaviour. Cluster analysis is an ensemble of methods designed to define clusters from a data set based on a difference matrix computed using a variety of methods. In the field of hydrological science, principal component analysis (PCA) has previously been used to define patterns in groundwater hydrographs in order to understand the areal distribution of different recharge characteristics and to determine if fewer wells can be measured for long-term groundwater monitoring without significant loss of information (Winter et al. 2000). PCA has been used more recently to combine groundwater hydrographs into a small number of groups displaying similar patterns of fluctuations, for which one representative hydrograph can be modelled (Upton and Jackson 2011).

The Eden Valley (Cumbria, England, UK; see Fig. 1) is a largely rural area with a relatively low population density. Agriculture and tourism are the main sources of income. The 
Fig. 1 Geographical setting of the Eden Valley catchment. The river Eden, main geographical features and geological ages are outlined. The locations of the hydrological stations are shown

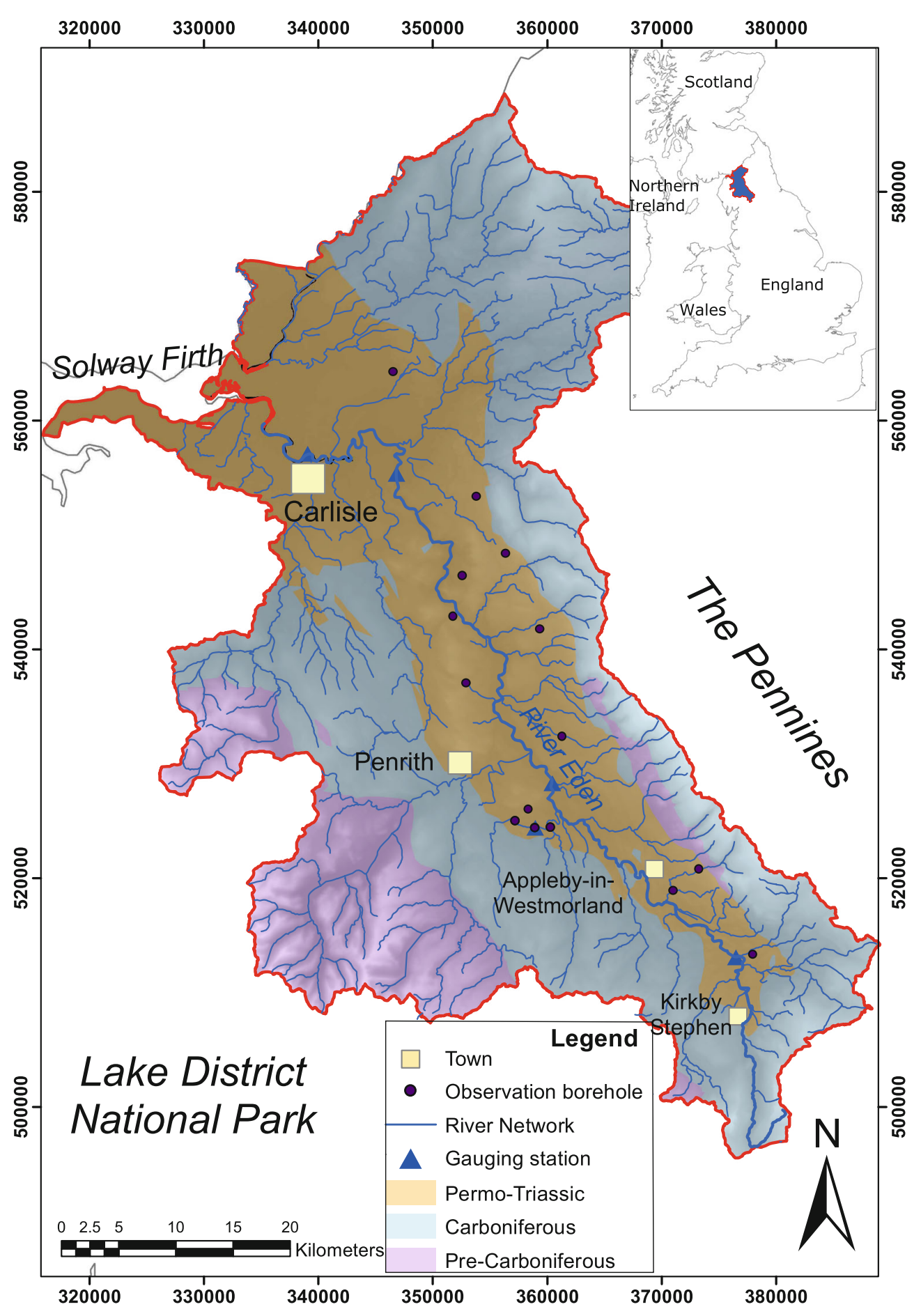

Permo-Triassic Sandstone forms the major aquifer in the region and could provide considerable groundwater resources (Butcher et al. 2006). There are a number of hydrological management issues at a wide range of scales in this area including flooding (Leedal et al. 2013; Mayes et al. 2006), pollutant transport, particularly nitrate (Wang et al. 2012; Wang et al. 2013), and ecology (Seymour et al. 2008; Hulme et al. 2012). There is no detailed calibrated regional groundwater model for the Eden Valley, but a refined conceptual understanding of groundwater flow regime would benefit better management and would underpin the construction of a regional groundwater model. Investigation of the impact of climate change on groundwater resource availability in the River Eden catchment would require a reliable understanding of the aquifer's response to the recharge at different time scales. Therefore, a systematic study of the available groundwater-level-time-series data is required using seasonal trend decomposition on daily hydrographs as described in this 
report. The geological and hydrogeological framework of the study area, the groundwater level data set and the seasonal trend decomposition method are described, then the method applied to study the differences between the different borehole groundwater response in terms of relative importance of the trend and seasonality components is described and results presented. Finally, using time-series clustering and correlation analysis on the decomposed groundwater-level time series, the implications for understanding the physical mechanisms involved in the Eden Permo-Triassic Sandstone aquifers are discussed. By applying the STL technique in conjunction with clustering and correlation methods to the analysis of groundwater hydrographs, it is shown that these approaches provide a systematic way of undertaking an initial evaluation of the conceptual understanding of groundwater flow. The groundwater level variations could then be used to identify, e.g. spatial differences in the physical properties of the aquifers, which provides the answer to the question: Can variation in groundwater response be used to identify parameterisation and understand differences in groundwater behaviour?

\section{Geological and hydrogeological setting}

The geology of the Eden Catchment is described in Allen et al. 1997; Hughes 2003a; Millward et al. 2003 and Stone et al. 2010. This report is concerned with the PermoTriassic rocks that crop out in the centre of the basin. They lie in a fault-bounded basin (approximately $50 \mathrm{~km}$ long and 5-15 km wide) that is straddled to the southwest by the Lake District and to the northeast by the North Pennines (Fig. 1). The geological setting of the PermoTriassic Sandstone and a cross-section across the Eden Valley are provided in Fig. 2. The Permo-Triassic strata dip gently to the north east. The Pennine Fault and associated North Pennine escarpment form the eastern boundary of what appears to be a half-graben, throwing PermoTriassic rocks against Carboniferous or Lower Palaeozoic rocks. To the west, the Permo-Triassic succession wedges out against Carboniferous strata (Allen et al. 1997).

Although the Lower Carboniferous succession is characterized by thickly bedded limestones which create elevated watersheds in the south with well-developed epikarst, no deep extensive karstic system has been reported in these or the Yoredale Group. In the northern half of the Eden catchment, the Upper Carboniferous poorly permeable Millstone Grit Group succeeds the Yoredale and there are outcrops of Coal Measures to the west of Armathwaite and further north (Hughes 2003a; Millward et al. 2003).

The oldest Permian Penrith Sandstone lies unconformably over the Carboniferous, overstepping onto progressively older rocks from north to south (Fig. 2). The Penrith Sandstone Formation was deposited in a structurally controlled intermontane basin broadly coincident with the present Vale of Eden. These largely aeolian sandstone reach a thickness of about $900 \mathrm{~m}$ in the center of the basin (see Table 1, which provides the main characteristics of the Permo-Triassic formations). The basal breccias, the Brockram, composed of angular fragments of dolomitised limestone embedded in a strongly cemented calcareous sandstone matrix, become progressively more dominant southwards - its inferred distribution according to Waugh (1970) is shown in Fig. 2. The Penrith Sandstone itself consists of well-rounded and well-sorted medium-to-coarse grains, but less homogeneous finergrained sandstone beds with thin mudstone intercalations are common, mainly at the top of the sequence and at the margins of the basin. In the northern part of the basin, parts of the top $100 \mathrm{~m}$ of the formation have been secondarily cemented by silica leading to stronger relief (Hughes 2003b; Millward et al. 2003; Stone et al. 2010). These cemented sandstones (Fig. 2) are highly indurated and have a very low hydraulic conductivity (Butcher et al. 2003; Waugh 1970), while beneath this zone, the Penrith Sandstone is moderately cemented and form some of the most permeable strata of the Permo-Triassic Sandstone of the Vale of Eden (Allen et al. 1997).

The Eden Shale Formation is an aquitard that overlies the Penrith Sandstone and consists mainly of mudstone and siltstone; sandstone, breccias and conglomerate intercalations being subordinate. This formation is poorly permeable and confines the Penrith Sandstone. The St Bees Sandstone Formation conformably overlies the Eden Shale Formation, occupying the axial part of the Vale of Eden syncline (see cross-section in Fig. 2). The formation consists mainly of very fine to finegrained indurated sandstone. Mudstone beds are subordinate, though they increase in abundance towards the boundary with the underlying Eden Shale Formation (Stone et al. 2010). In the northern part of the catchment (Carlisle basin, Figs. 1 and 2), the Kirklinton Sandstone forms the upper part of the Sherwood Sandstone Group. It is a more aeolian sandstone that displays a wide range of transmissivities in this area (Allen et al. 1997).

More than $75 \%$ of the Eden catchment bedrock geology is covered by Quaternary superficial deposits (Fig. 2). These cover much of the Permo-Triassic Sandstone and seem likely to have an impact on recharge and its distribution (Butcher et al. 2006). Nevertheless, exposed areas of sandstone are present, mainly in the southern part of the catchment and many stretches of the River Eden can be seen to show sandstone outcropping in its banks. The stratigraphy of these deposits is complex, with inter-digitations of sand, gravel, silt and clay that may each develop their own piezometric level, resulting in complex perched water tables above the bedrock formations (Allen et al. 1997).

The Penrith and St Bees Sandstone are characterized by moderate-high permeability and porosity. Table 1 summarizes the properties of the Permo-Triassic Sandstone aquifers, in the 
Fig. 2 Simplified bedrock geology (from the BGS 1:50,000 map), occurrence of superficial deposits (from the BGS 1:50,000 map) and varying lithologies within the Penrith Sandstone according to Waugh (1970) are shown and main geological features are shown. A west-east geological cross-section is provided. The location of the observation boreholes is displayed



Vale of Eden and the Carlisle Basin (northern part of the catchment). While the Penrith Sandstone is characterized by both vertical and horizontal heterogeneity (in terms of cementation and grain size), the St Bees Sandstone tends to act as one aquifer. The thickness information provided in Table 2 cannot be considered as the aquifer thickness because of the heterogeneous and layered nature of these sandstone aquifers.

The regional groundwater flow generally appears to be dominated by intergranular flow, whilst flow into boreholes is predominantly contributed by fractures; however, regionally, the fracture networks are not necessarily well connected (Allen et al. 1997).

The principal aquifer types within the Permo-Triassic rocks are:

Unconfined sandstone with no, or little, superficial deposit cover

Unconfined sandstone with superficial deposits more than $5 \mathrm{~m}$ thick and an unsaturated zone within the sandstone 
Table 1 Geological and hydrogeological information (including core data from Allen et al. 1997) concerning the main aquifers in the Eden Valley catchment: the Penrith Sandstone aquifer (Permian) and the St Bees Sandstone aquifer. The Penrith Sandstone is more permeable on average, but some very low values have been measured. The occurrence and thickness of the formations are given for the Vale of Eden and the Carlisle Basin (northern part of the catchment)

\begin{tabular}{|c|c|c|c|c|c|c|c|c|}
\hline \multirow[t]{2}{*}{ Age } & \multirow[t]{2}{*}{ Group } & \multicolumn{2}{|l|}{ Carlisle Basin } & \multicolumn{2}{|l|}{ Vale of Eden } & \multicolumn{3}{|c|}{ Aquifer characteristics } \\
\hline & & Formations & $\begin{array}{l}\text { Thickness } \\
\text { (m) }\end{array}$ & Formation & $\begin{array}{l}\text { Thickness } \\
\text { (m) }\end{array}$ & & & \\
\hline \multirow[t]{2}{*}{ Triassic } & \multirow[t]{2}{*}{ Sherwood Sandstone } & Kirklinton Sandstone & $10-100$ & - & - & Aquifer & - & - \\
\hline & & St Bees Sandstone & $<500$ & St Bees Sandstone & $<350$ & & $\begin{array}{l}\text { Hydraulic conductivity } \\
\text { (m/day) } \\
\text { Porosity }(\%) \\
\text { Transmissivity ( } \mathrm{m}^{2} / \text { day) }\end{array}$ & $\begin{array}{l}0.23-0.39 \\
25.3-30.1 \\
167-276\end{array}$ \\
\hline \multirow[t]{3}{*}{ Permian } & \multirow[t]{3}{*}{-} & St Bees Shale & $<90$ & Eden Shale & $<180$ & Aquitard & - & - \\
\hline & & \multirow[t]{2}{*}{$\begin{array}{l}\text { Penrith Sandstone } \\
\text { (present at depth) }\end{array}$} & \multirow[t]{2}{*}{$0-?$} & \multirow[t]{2}{*}{ Penrith Sandstone } & \multirow[t]{2}{*}{$<900$} & \multirow[t]{2}{*}{ Aquifer } & $\begin{array}{l}\text { Perm. (m/day) } \\
\text { Porosity (\%) }\end{array}$ & $\begin{array}{l}0.3-3.95 \\
21.1-27.8\end{array}$ \\
\hline & & & & & & & Transmissivity (m²/day) & $10-2,000$ \\
\hline
\end{tabular}

Confined sandstone, showing a groundwater level that fluctuates within superficial deposits

The river flow in the Eden catchment is derived from surface water flowing from adjacent uplands (Carboniferous Limestone and older formations), direct runoff within the Vale of Eden and base flow contribution from the PermoTriassic Sandstone and other minor aquifers. By examining the data from an observation borehole network (Lafare et al. 2014) it is hoped that a better appreciation of the hydrogeology of the Permo-Triassic Sandstone can be produced.

\section{Data and methodology}

Data from 26 observation boreholes obtained from the Environment Agency have been used for this study and their location is presented in Fig. 2. Further details of the boreholes and their setting (including geological logs) can be found in Lafare et al. (2014).

Daily groundwater-level time series are available from 18 boreholes for a time period between 2000 and 2012. Figure 3 shows the normalized (centered by subtracting the average) groundwater-level time series plotted for each of these 18 boreholes. All these boreholes were drilled in the PermoTriassic Sandstone Formation with 12 in the Penrith Sandstone and 6 in the St Bees Sandstone (Lafare et al. 2014). It can be seen that the data from different observation boreholes provide a variety of groundwater hydrograph behaviours, in terms of shape and amplitude. Geographical, geological and hydrogeological information were gathered and used to provide a descriptive interpretation of the setting of each borehole. This information is summarized in Table 2 for the 18 boreholes.
In order to better describe and assess the features contained in the groundwater level responses, the STL method (Cleveland et al. 1990), which uses the locally weighted regression (LOESS) technique that was first proposed by Cleveland (1979) and later modified by Cleveland and Devlin (1988), was employed. The regression can be linear or a higher polynomial. The weighting reduces the influence of outlying points and is an example of robust regression. The nonparametric nature of the STL decomposition technique enables detection of nonlinear patterns in long-term trends that cannot be assessed through linear trend analyses (Shamsudduha et al. 2009).

Each time series was processed in order to meet with the requirements when using the STL procedure. The observations must form a regularly spaced time series where the seasonal period is fixed. In principle, missing data can be handled in the STL procedure but the STL routine used in this study does not currently allow this (Chandler and Scott 2011); therefore, the longest continuous period recorded was extracted for each time series, a correction and filling of short gaps using interpolation was applied, and daily time-series objects were created. The STL decomposition method was applied to each time series, i.e.

$Y_{t}=T_{t}+S_{t}+R_{t}$

Where $Y_{t}$ is the groundwater level at time $t, T_{t}$ is the trend component, $S_{t}$ is the seasonal component representing for example the annual cycles, and $R_{t}$ is an irregular (remainder) component that can be related to short-term variations as shown in Fig. 4 which generally represents differences in seasonal response, measurement error as well as an unexplained part (white noise). Different choices of smoothing parameters were experimented with to extract trend and seasonal components for 


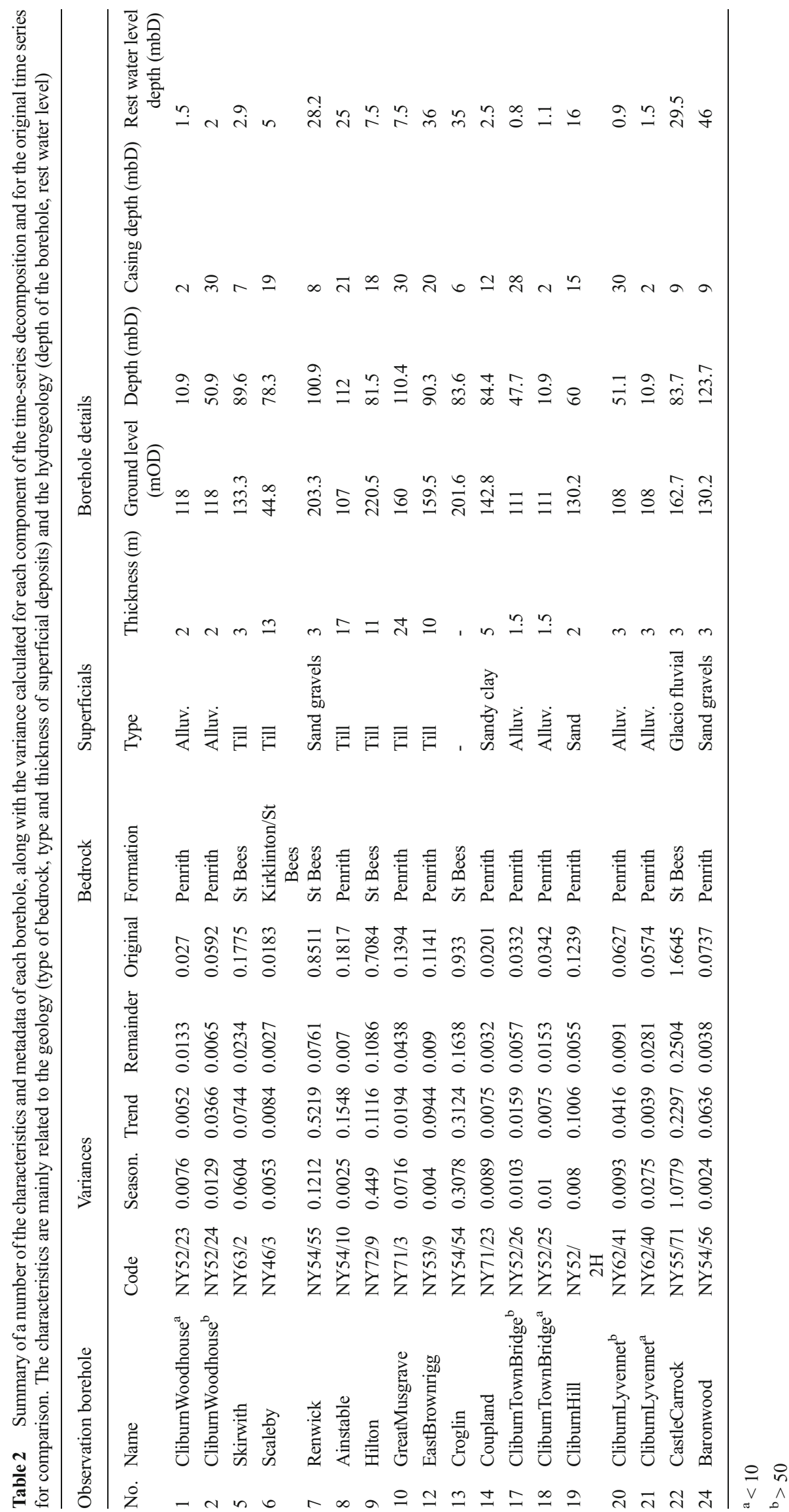


Daily groundwater level fluctuations (m)

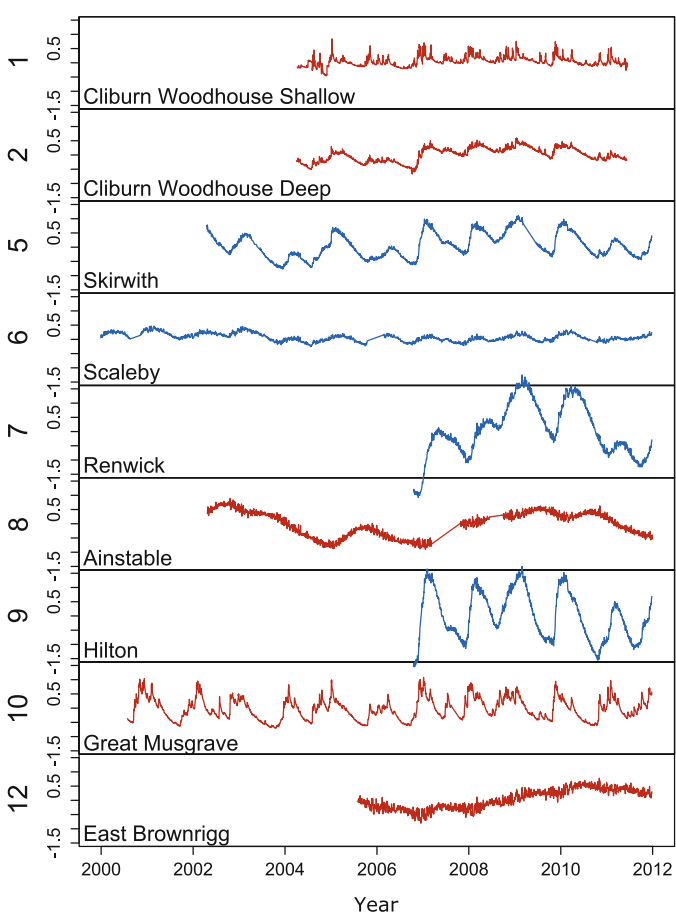

Fig. 3 Groundwater level hydrographs for the 18 daily time series. The groundwater-level time series are all centered by subtracting the mean groundwater level of each hydrograph in order to make the graphical

each hydrograph as recommended by Cleveland et al. (1990); Carslaw (2005) and Shamsudduha et al. (2009).

The statistical dispersion of each of the components obtained after decomposition was compared to the statistical dispersion of the original signal as a percentage, in order to develop a relationship between the hydrogeological settings and enable the characteristics of the hydrographs to be investigated. The variance of each time-series component is calculated and

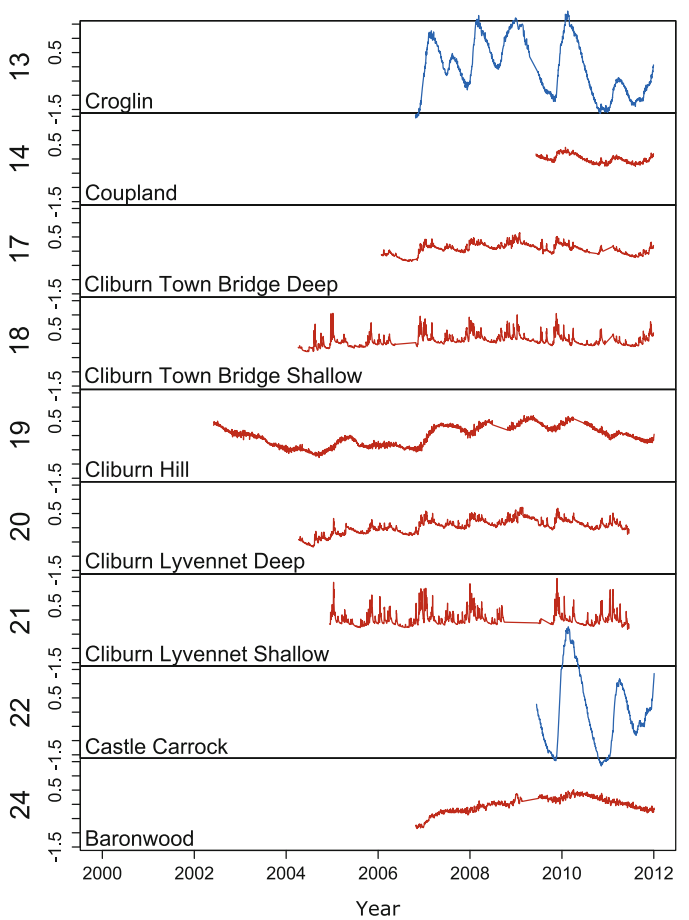

comparison easier. The hydrographs are coloured according to the main aquifer: red (Penrith Sandstone) and blue (St Bees/Kirklinton Sandstone)

provided in Table 2. To emphasize the relative importance of the variance associated to each decomposition component in comparison with the original signal, a ratio of this variance with the variance of the original signal was calculated. That is, in the case of the trend:

Ratio $_{\text {trend }}=\frac{\text { Variance }_{\text {trend }}}{\text { Variance }_{\text {original }}}$
Fig. 4 Example of daily groundwater-level-time-series decomposition using the STL algorithm. The time series corresponds to the Skirwith borehole (No. 5) in the St Bees Sandstone Formation

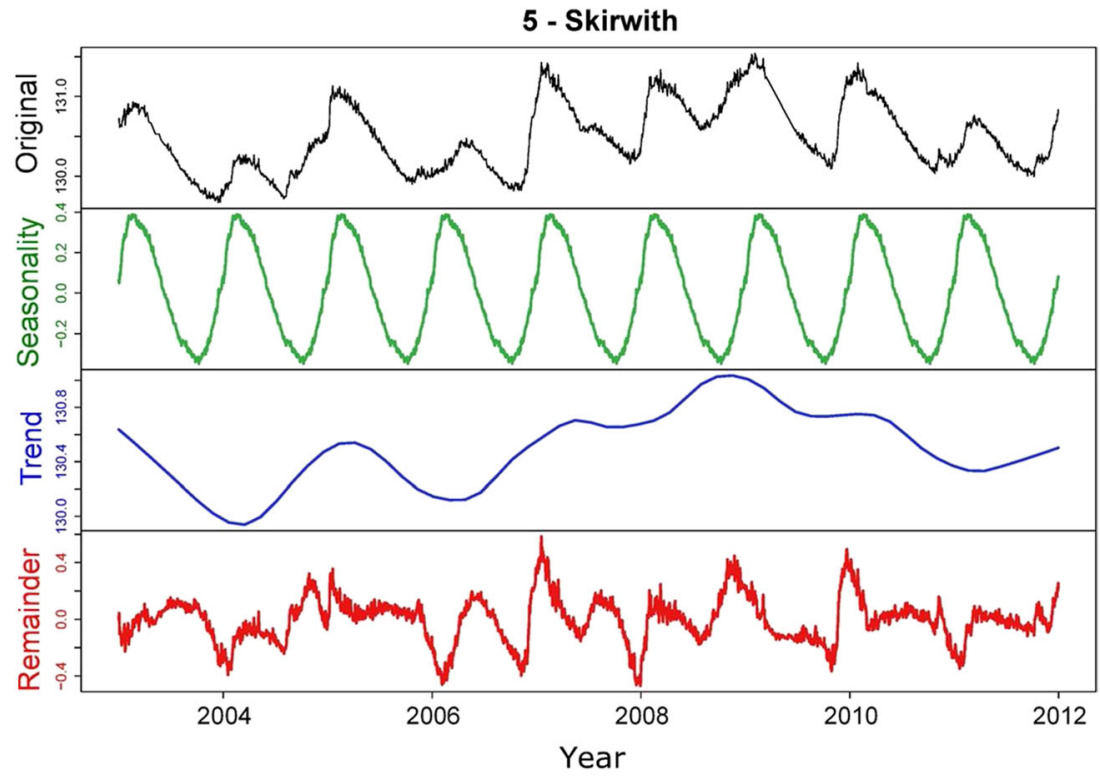


In order to define the relative importance of the different time-series components, a time-series clustering approach was applied. This enabled the partitioning of different hydrograph components into groups based on distance, in that time series in the same cluster are considered to be similar. The measure of distance between the time series is performed here using dynamic time warping (DTW; Keogh and Pazzani 2001), which finds optimal alignment between two time series and is considered as an efficient measure of similarity/dissimilarity between time series (Zhao 2012). A distance matrix can be computed, using the distances between each pair of time series by DTW. Hierarchical cluster analysis using Pearson's correlation coefficient and the complete linkage method is then carried out on the distance matrix. The complete linkage method is a hierarchical agglomerative method, which has been previously used, e.g. in climatology applications and has produced more physically interpretable clusters than, for example, the Ward's clustering method (Hannah et al. 2000). The component hydrographs are, therefore, combined into an optimum number of groups according to their alignment. The methodology is applied for the time series corresponding to the three different components.

Finally, correlation analyses are performed on the component time series to obtain further information about the behaviour of the different hydrographs. The autocorrelation is assessed only for the remainder, the seasonality and trend component being by definition highly autocorrelated. The aim is to outline the memory of a system (Bouchaou et al. 2002; Mangin 1984; Padilla and Pulido-Bosch 1995) while determining the autocorrelation of the remainder that represents more effectively the local effects and short-term events. Finally, cross-correlations were performed between the different decomposition components and rainfall and river-flow time series. Both river flow and GWL data were obtained from the UK Environment Agency, while the rainfall time series were extracted at each borehole location from the Centre for Ecology \& Hydrology (CEH) gridded estimates of daily areal rainfall for the United Kingdom. The daily river flow and rainfall time series are used as input signal, as well as cumulative rainfall over increasing time windows (as undertaken by Fiorillo and Doglioni 2010). The cumulative rainfall time series were constructed over 10, 30, 60, 120, 180, 270 and 360day-long time windows. A sample of cross-correlations for representative boreholes is provided in Table 3 in order to support the following discussion.

\section{Results and discussion}

\section{Graphical comparison of the decomposition}

The hydrographs of observation boreholes within this data set provide a variety of groundwater level behaviour, in terms of shape and amplitude. These differences have been explored by time-series decomposition using the STL method. Four representative examples of the decomposition results are presented in Fig. 5. The standardized seasonality, trend and remainder components are represented on a single plot for four groundwater hydrographs.

The decomposition of the hydrograph from the borehole No. 8 (Ainstable) is presented in Fig. 5a. This borehole is drilled in the Penrith Sandstone, covered by $15 \mathrm{~m}$ of boulder clay. The unsaturated zone is approximately $25 \mathrm{~m}$ thick. The decomposition is characterized by a strong trend component that explains most of the variability of the original signal. The seasonality and the remainder components display similar smaller amplitude. High frequency (daily) variations can be observed on the remainder components, that could be partially related to the rainfall (a correlation coefficient of 0.18 is obtained for a lag 0 , see Table 3 ). The seasonality is best correlated to the cumulative rainfall over a time window of 180 days (correlation coefficient of 0.56 ) for a particularly long lag (237 days), potentially indicating delayed groundwater recharge and longer flow pathways.

Figure $5 \mathrm{~b}$ shows, in the same way, the decomposition of the hydrograph from the borehole No. 9 (Hilton). This borehole is drilled in the St Bees Sandstone, covered by $10 \mathrm{~m}$ of glacial till. The unsaturated zone is approximately $7.5 \mathrm{~m}$ thick. In this case, the seasonality is the component that shows the higher amplitude and explains most of the variability of the original signal. This seasonality is best correlated to the cumulative rainfall over a time window of 180 days (correlation coefficient of 0.56 ) for a shorter lag (51 days), indicating a less important delay. The remainder component appears smoother than for No. 8, with lower frequency variations.

Figure 5c,d shows the decomposition of the hydrographs from two observation boreholes situated very close to each other on the bank of the River Leith, south of Cliburn (Nos. 18 and 17). Borehole 18 is $10 \mathrm{~m}$ deep, while borehole 17 is $50 \mathrm{~m}$ deep. Despite the fact that these boreholes are both drilled in the Penrith Sandstone aquifer formation, differences in behaviour are observed. The remainder component for the shallow borehole (No. 18) has clearly the higher value, which represents a relatively strong response to short-term events and seems likely to be related to good connectivity between the nearby river and the shallower parts of the aquifer. This is confirmed by the examination of the cross-correlation provided in Table 3-total and remainder components are highly correlated (correlation coefficient between 0.5 and 0.6) to the rainfall (with a lag of 1 day) and to the river flow (with a null lag). The influence of the remainder component appears less important in the case of the deeper borehole (No. 17). In this case the cross-correlation with the rainfall and with the river flow increases with the STL decomposition, from respectively 0.19 and 0.24 (lag=1 day) for the total component to respectively 0.42 and 0.40 (lag=1 day) for the remainder 


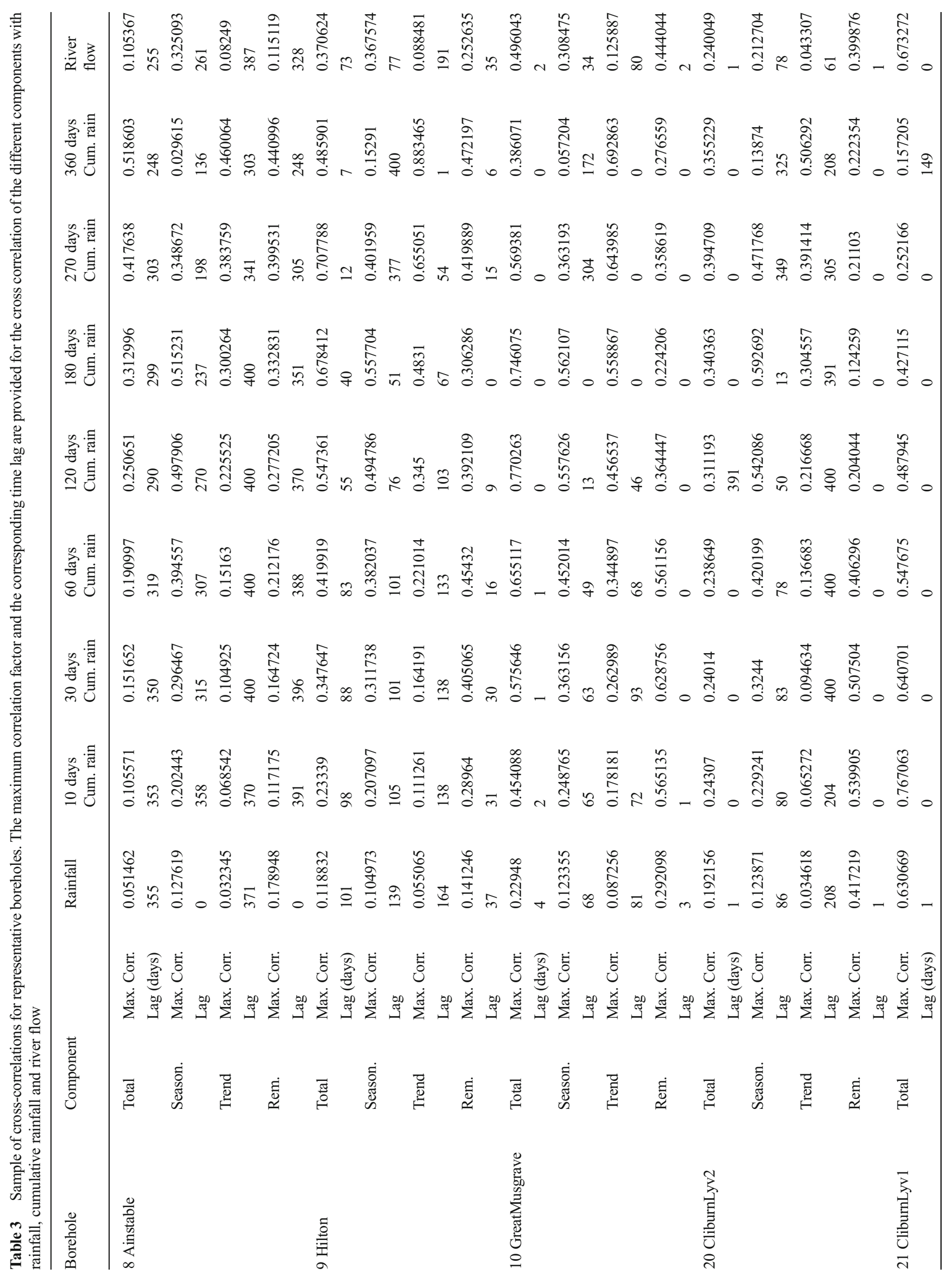


component (de-trended and de-seasonalised). For this borehole, the STL decomposition effectively extracts the groundwater level variation correlated to short-term events. Moreover, on average, the head in this deep piezometer is higher than in the shallow one, indicating potential upward groundwater movement. It seems likely that such differences in behaviour are due to vertical heterogeneity within the Penrith Sandstone aquifer. These observations can be similarly done for the other paired boreholes located close to the River Leith (boreholes Nos. 1-2 and 20-21).

The observation of the general evolution of the trend components (Fig. 5) reveals similar patterns common to the majority of the boreholes. Lower values over the period 2004 2006, an increase to a greater or lesser extent from 2007 to 2009 , and finally a decrease through the years 2010-2012. This is thought to be related to drought events (2004-2006 and 2010-2012) in the UK, that are described, e.g. by Marsh (2007) and Marsh et al. (2013); however, the 2004-2006 drought event affected the south and east of England more significantly than the north-west, while the 2010-2012 drought was more widespread with the north-west more affected in the early part of the event.

\section{Estimation of the variability of each component and interpretation}

An overview of the results and of the main characteristics associated to each borehole hydrograph is presented in Table 2. It summarizes the geology in terms of bedrock, type and thickness of superficial deposits, if any, and the construction details of the borehole and rest water level. It also includes the variances of the trend, the seasonality and the remainder, along with the variance of the original time series in order to assess the relative variability of each component. This relative variability (represented by the ratios obtained from the variances and defined by Eq. 2) is then plotted in Fig. 6.

The dots corresponding to each borehole are coloured differently depending on whether they were drilled in the Penrith Sandstone or the St Bees/Kirklinton Sandstone (Table 2; Fig. 6) and can be used to examine the relationships between the geological or hydrogeological setting associated with each borehole and the characteristics of its associated hydrograph.

Investigating the differences between groundwater hydrographs in the Penrith Sandstone and those from the St Bees Sandstone, it appears that the decomposition is characterized by the stronger trend component in terms of variance which is representative of the Penrith Sandstone. For example, the variance of the trend component represents more than $80 \%$ of the variance of the original time series for the borehole Nos. 8, 12, 19 and 24. These boreholes are clearly closely grouped in Fig. 6a-c. On the other hand, the stronger seasonal components in terms of variance are obtained for boreholes situated in the St Bees Sandstone aquifer; the variance of the 


\section{a}

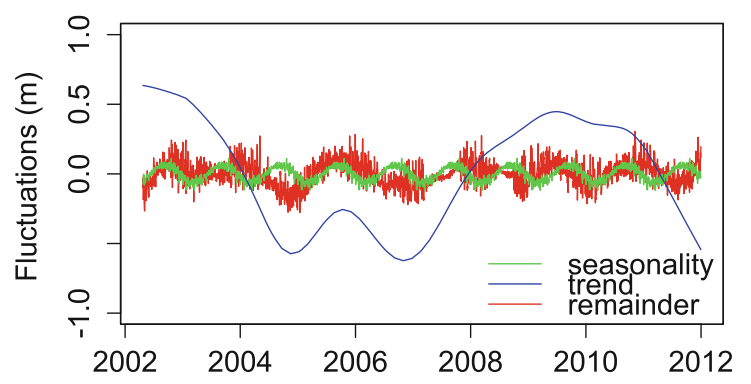

b

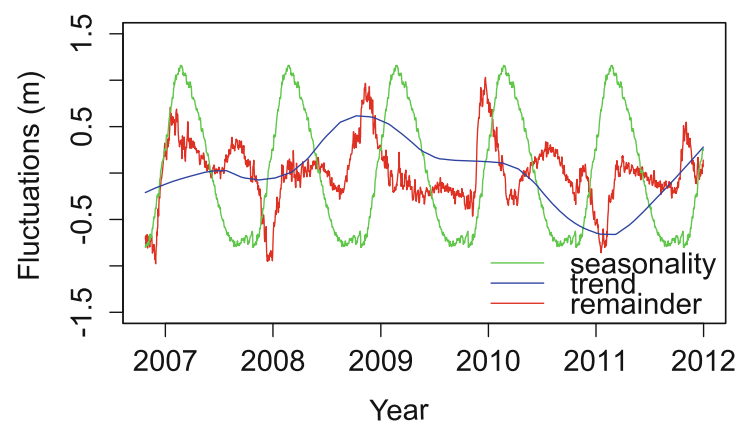

C CliburnTownBridgeS - no 18

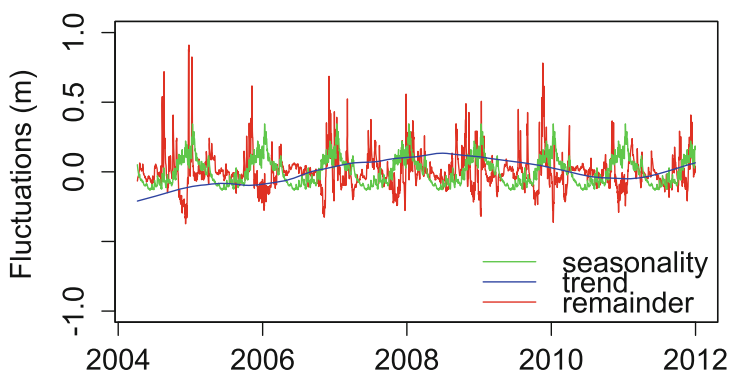

d CliburnTownBridgeD- no 17

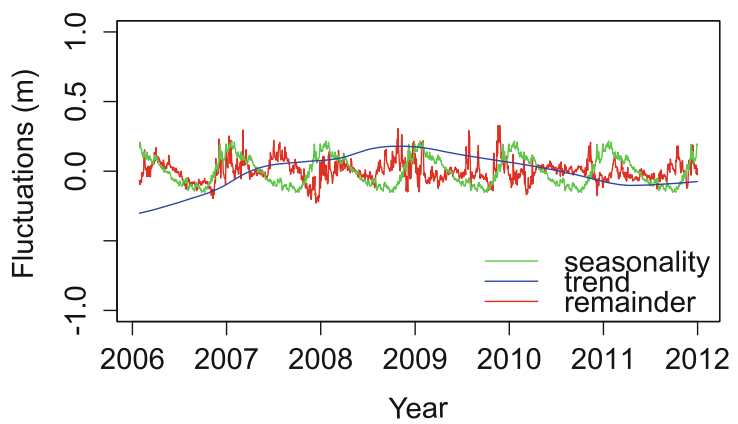

Fig. 5 The standardized seasonality, trend and remainder components are presented for groundwater level (GWL) in four observation boreholes: a Ainstable No. 8, b Hilton No. 9, c Cliburn Townbridge Shallow No. 18 and d Cliburn Townbridge Deeper No. 17

Fig. 6 Graphical comparison of the ratios (Eq. 2, expressed as percentages) associated to each decomposition component: a trend ratio vs seasonality ratio, $\mathbf{b}$ trend ratio vs remainder ratio and c remainder ratio vs seasonality ratio. Annotations are explained directly on the figure
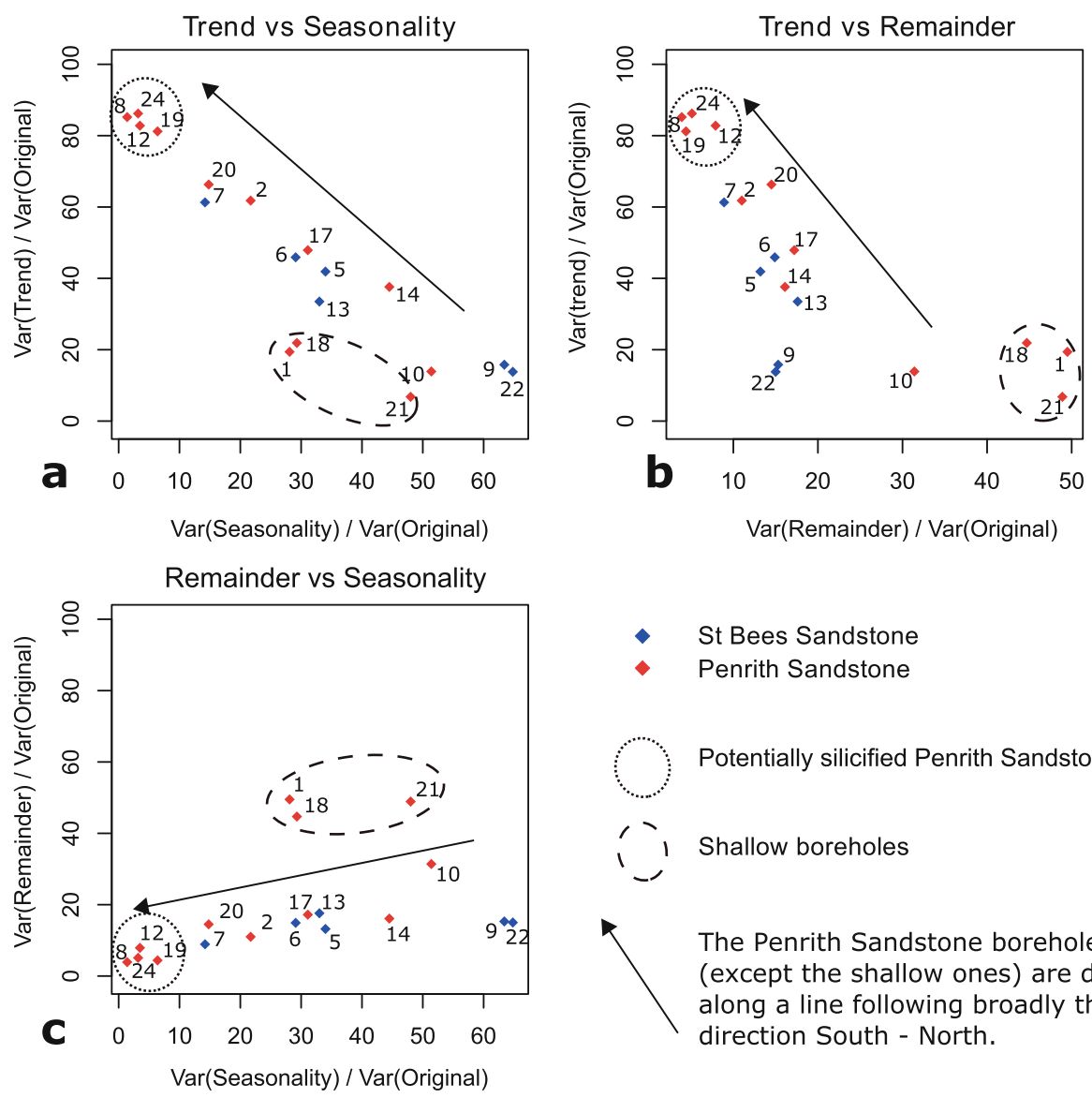

- St Bees Sandstone

- Penrith Sandstone

Potentially silicified Penrith Sandstone

1 Shallow boreholes

The Penrith Sandstone boreholes (except the shallow ones) are distributed along a line following broadly the direction South - North. 
seasonal component represents more than $60 \%$ of the variance of the original time series for the borehole Nos. 9 and 22, as shown clearly in Fig. 6a,b, which can be explained by the differences in porosity, storage, hydraulic conductivity and the distribution of these properties (see Table 1) between the Penrith and the St Bees Sandstone. The St Bees Sandstone is exhibiting lower hydraulic conductivity than the Penrith Sandstone (median of $0.23 \mathrm{~m} /$ day for the St. Bees vs $1.35 \mathrm{~m} /$ day for the Penrith) and slightly lower porosity (median of $24.1 \%$ vs $26.9 \%$ ). As described in the preceding, the Penrith Sandstone demonstrates both vertical and horizontal heterogeneity in terms of cementation and grain size, while the St Bees Sandstone is more homogeneous and tends to act as one aquifer unit. The vertical distribution of hydraulic properties in the Penrith can result in low-permeability layers isolating the deeper parts of the aquifer from recharge, while the lower hydraulic conductivity in the St Bees could enhance seasonal fluctuations.

Figure 2 presents the distribution of the different lithologies (Brockram, non-silicified and silicified, from Waugh 1970) in the Penrith Sandstone along with the position of the observation boreholes. It can be seen that the borehole hydrographs characterized by the stronger trend $(8,12,19$ and 24$)$ are all located within the silicified northern part of the Penrith Sandstone outcrop. This is likely to prevent the aquifer responding efficiently to localized recharge and lead to smaller amplitudes of the seasonality and the remainder. These boreholes situated in the silicified $(8,12,19$ and 24) and non-silicified $(1,2,17,18,20,21)$ areas of the Penrith Sandstone are all characterised by unconfined conditions (Table 2). It could be argued that a higher storage capacity is associated with the potentially thicker Penrith Sandstone Formation closer to the centre of the basin (boreholes 8, 12, 24). This is a possibility; however, the effective thickness of the aquifer is largely unknown because of the heterogeneous nature of the formation (namely the vertical anisotropy due to fracturing, layering and cementation).

Borehole No. 10 and to a lesser extent borehole No. 14 show a different response not typical of the northern Penrith Sandstone with a relatively strong seasonal (the seasonal variance attains more than $40 \%$ of the variance of the original signal) and remainder component (more than $30 \%$ for borehole No. 10). These boreholes are situated in the southern part of the Penrith Sandstone outcrop, where the presence of Brockram facies is important. These breccias are composed of angular fragments of dolomitised limestone embedded in a strongly cemented calcareous sandstone matrix, and can be more or less intensively fractured and subject to dissolution in parts. Breccias and conglomerates that contain mainly carbonate clasts and calcite cement are likely to function like other carbonate rocks (Ford and Williams 2007). Therefore, fracture hydraulic conductivity could well be more dominant in this region producing some rapid flow pathways and response to seasonal recharge that would explain this anomalous behaviour.

The groundwater level responses of the paired observation boreholes situated on the bank of the river Leith, south of Cliburn (1-2, 17-18 and 20-21) appear to demonstrate vertical heterogeneity and are influenced by surface-water/groundwater interaction. Each pair comprises a shallow (10 m deep) and a deep (50 m deep) borehole. The results consistently show that the depth of the borehole has a distinct influence on the piezometric response. Indeed, the shallow boreholes are characterized by the variance of the remainder component reaching $45-55 \%$ of the variance of the original time series (compared to less than $20 \%$ for the deep boreholes, see Table 2 and Fig. 6). The hydrographs obtained for the shallower boreholes are likely to be more influenced by the fluctuations of the river stage from nearby streams, which suggests the importance of vertical heterogeneity within the Penrith Sandstone (Seymour et al. 2008), and is consistent with the presence of beds characterized by different grain size and sorting, as well as secondary cemented beds. Setting aside the shallow boreholes, it can be observed that the strength of trend increases in the Penrith aquifer from the south (characterized by the presence of Brockram) to the north, while the strength of the seasonality component decreases (Fig. 6a).

The influence of stream stage via river-aquifer interaction on the hydrograph response is clearly demonstrated by the great importance of the signal remainder in the shallow boreholes situated in the region of Cliburn, near to river Leith (Nos. 1, 18, and 21), as well as the strong cross-correlation with the river flow (Table 3). It was not possible to find any clear relationships with other potential factors, such as the characteristics of the superficial deposits or the influence of important geological features (e.g. faults, the Armathwaite dyke, relationships with the carboniferous limestone).

\section{Time-series clustering}

In order to explore relationships between the decomposition time series further, the different time-series components were examined in more detail. A time-series clustering approach was used to partition the different hydrograph components into groups based on distance so that time series in the same cluster are considered to be similar. This clustering methodology is applied for the time series corresponding to the seasonality component (Fig. 7a) and the trend component (Fig. 7b). The breaks in the clustering dendrogram and cluster validity index are used to define a suitable number of groups of boreholes displaying a similar time series in terms of alignment.

Assessing the seasonality component (Fig. 7a), boreholes 22, 13 and 9 can be easily grouped in an independent cluster. They are all located in the St Bees Sandstone aquifer and are characterized by a time-series variability mainly dominated by the seasonality. The remaining boreholes are divided into two 


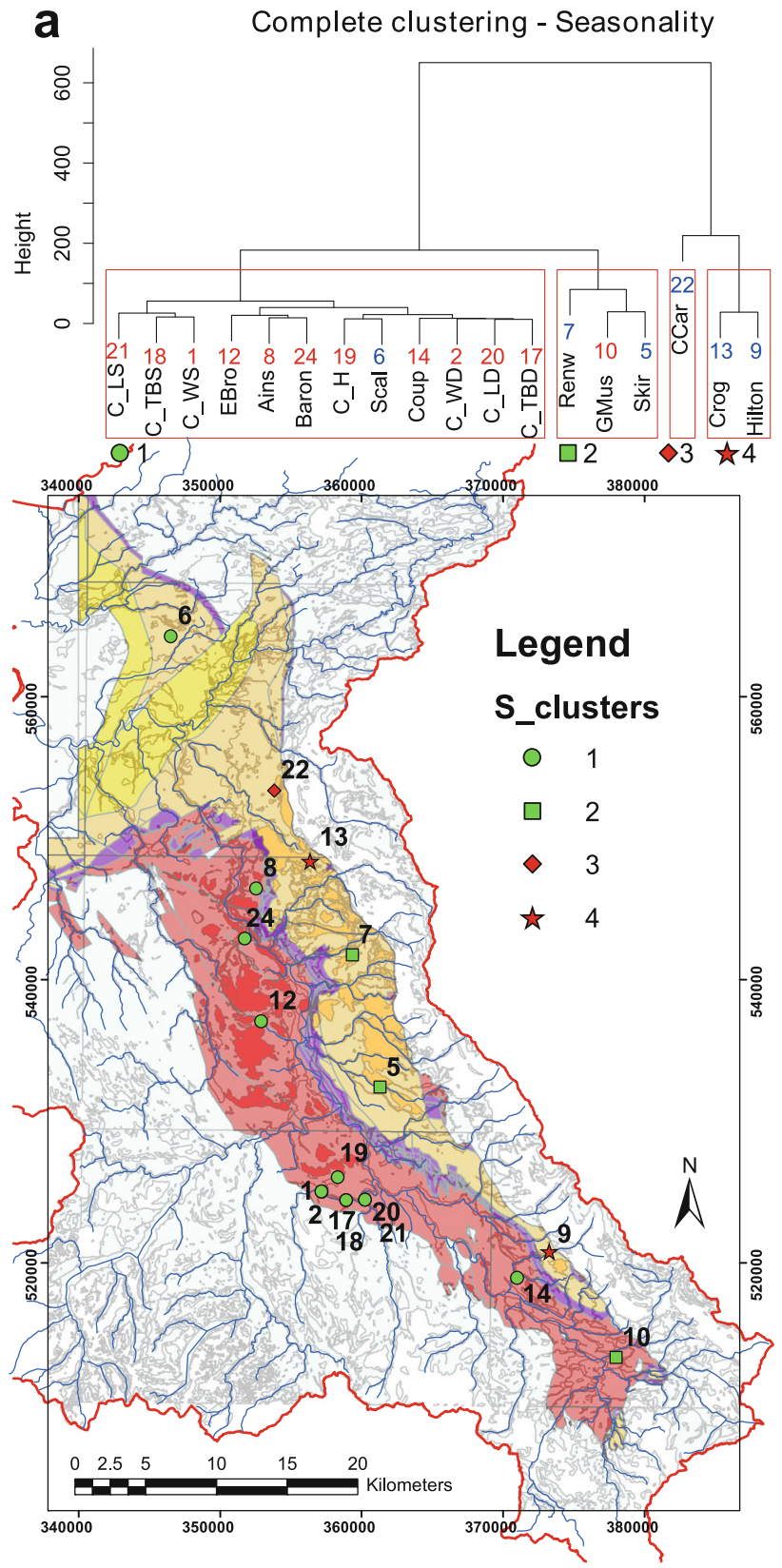

b Complete clustering - Trend

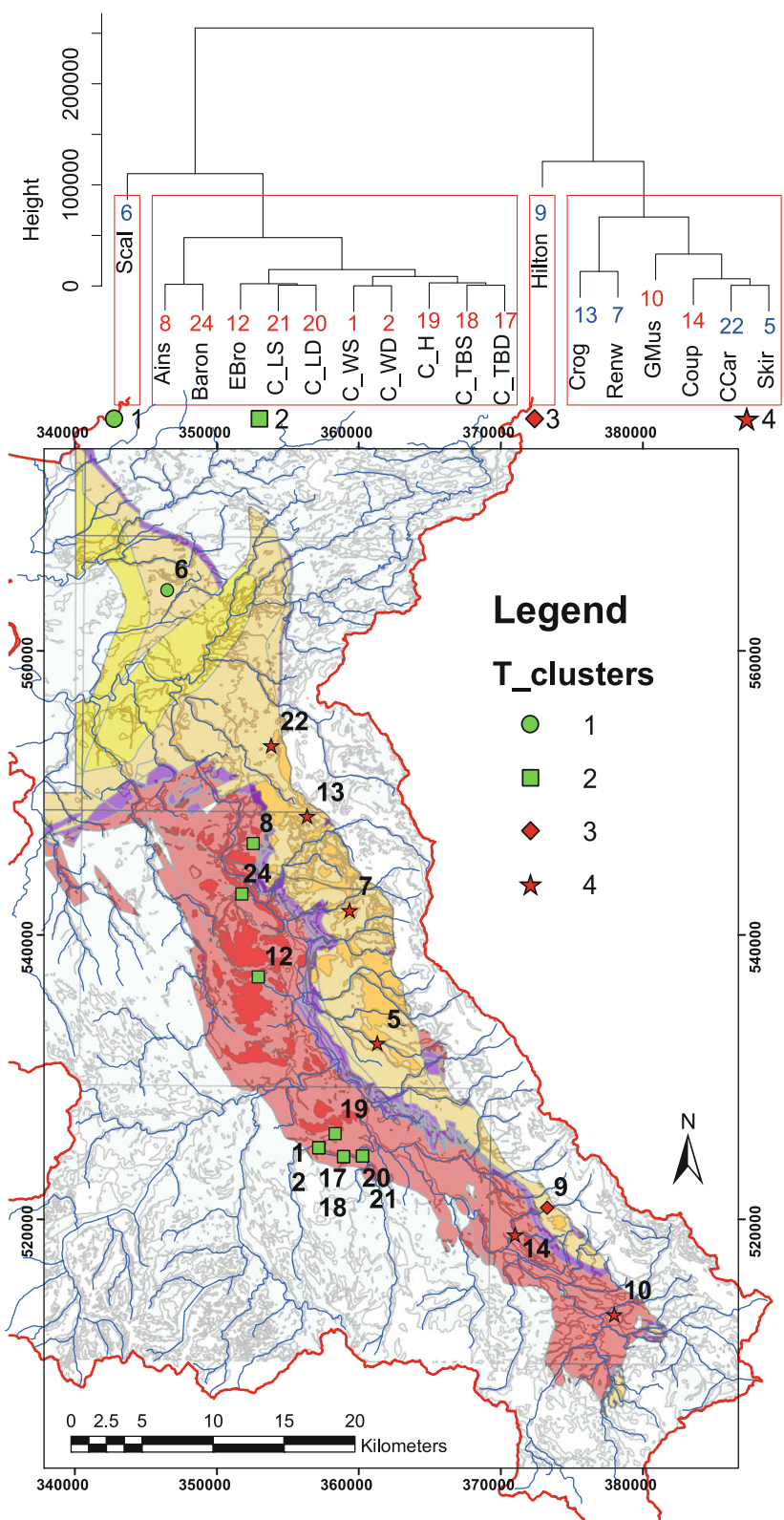

Fig. 7 Results of the cluster analysis using complete clustering and dynamic time warping for the a seasonality and $\mathbf{b}$ trend time series. The results are also shown on a map with different symbols associated to each cluster

main groups: 12 boreholes comprising all but one borehole drilled in the Penrith Sandstone and one borehole drilled in the Kirklinton Sandstone; and three boreholes comprising two boreholes drilled in the St Bees Sandstone (No. 7 and No. 5) and borehole No. 10. The latter borehole displays anomalous behaviour not typical of the Penrith Sandstone, with a seasonal component similar to that obtained for hydrographs measured in the St Bees. The differences in the behaviour hydrographs can, therefore, be mainly explained by the different bedrock lithologies into which the boreholes are completed. The cross-correlations provided in Table 3 shows that the seasonality of both borehole No. 9 and 10 are better correlated to the cumulated rainfall over a time window of 180 days (correlation coefficient of 0.56 ) but with a lag more important for borehole No. 9 (51 days) than for borehole No. 10 (null lag). The cross-correlation for borehole No. 5 is similar to No. 9. The cluster comprising both St Bees borehole and No. 10 Penrith borehole could, therefore, be related to similar recharge patterns, with a longer delay for St Bees boreholes.

Analysis of the trend component (Fig. 7b), produces a significant cluster containing 10 boreholes including all but two of the boreholes drilled in the Penrith Sandstone aquifer. These are identified with reasonably aligned long-term trends. Boreholes 10 and 14, which are drilled in the southern part of 
the Penrith Sandstone, fall in a cluster which also contains most of the boreholes drilled in the St Bees Sandstone. This could be due to similar recharge and flow processes because they are situated on sub-catchments potentially affected by the recharge on the Pennines fells, that form the eastern boundary of the Eden Valley (Figs. 1 and 2), as are the St Bees boreholes. Besides both trend components for boreholes No. 10 and 9 are better correlated with cumulative rainfall over a time window of 360 days (respectively the correlation coefficient is 0.88 for a lag=1 day and 0.69 for a null lag). This agrees with a similar influence of the long-term recharge. Besides, boreholes 10 and 14 are drilled into the fractured Brockram and so might be expected to show an increased seasonal effect (see the preceding).

\section{Correlation analysis}

The autocorrelation was calculated for each of the remainder time series, and plotted in Fig. 8. The autocorrelation values range from -1 (perfect negative correlation) through 0 (no correlation) to +1 (perfect positive correlation). The results are divided into three groups, based on the analysis of the decomposition. The correlograms of the remainders obtained for the boreholes drilled in the northern Penrith Sandstone are displayed in Fig. 8a, in the southern Penrith in Fig. 8b, and in the St Bees Sandstone in Fig. 8c. In each plot, a black dashed line indicates the autocorrelation value of 0.2 , in order to outline the memory of the borehole using the de-correlation time lag (Benavente and Pulido-Bosch 1985). Most of the remainders from boreholes drilled in the St. Bees sandstone are characterized by correlograms showing a slightly decreasing slope and autocorrelation values higher than 0.2 over a relatively long time lag (from 45 to 85 days, see Fig. 8c), indicating a strong memory effect, revealing a rather homogeneous system characterized by significant groundwater storage, which is consistent with the properties of the St Bees Sandstone aquifer, as it tends to act as a single aquifer, dominated by granular flow and characterized by important storage effect. It can be observed that the slope of the correlogram is initially very low, and tends to increase after approximately 20 days, which is not the case for borehole No. 6 at Scaleby, which was partly drilled in the Kirklinton Sandstone (which forms the upper part of the Sherwood Sandstone Group) in the northern part of the catchment. It is a more aeolian sandstone that displays a wide range of transmissivities in this area (Allen et al. 1997). This potential higher heterogeneity appears while observing the initially high slope of the correlogram during the first 5 days, followed by a lower slope. On the other hand, the southern Penrith correlograms display a steeper slope (especially during the first 20 days, see Fig. 8 b) and shorter decorrelation times (from 17 to 43 days), which corresponds to a lower-memory aquifer system, characterized by a higher heterogeneity and potentially the presence of more rapid flow

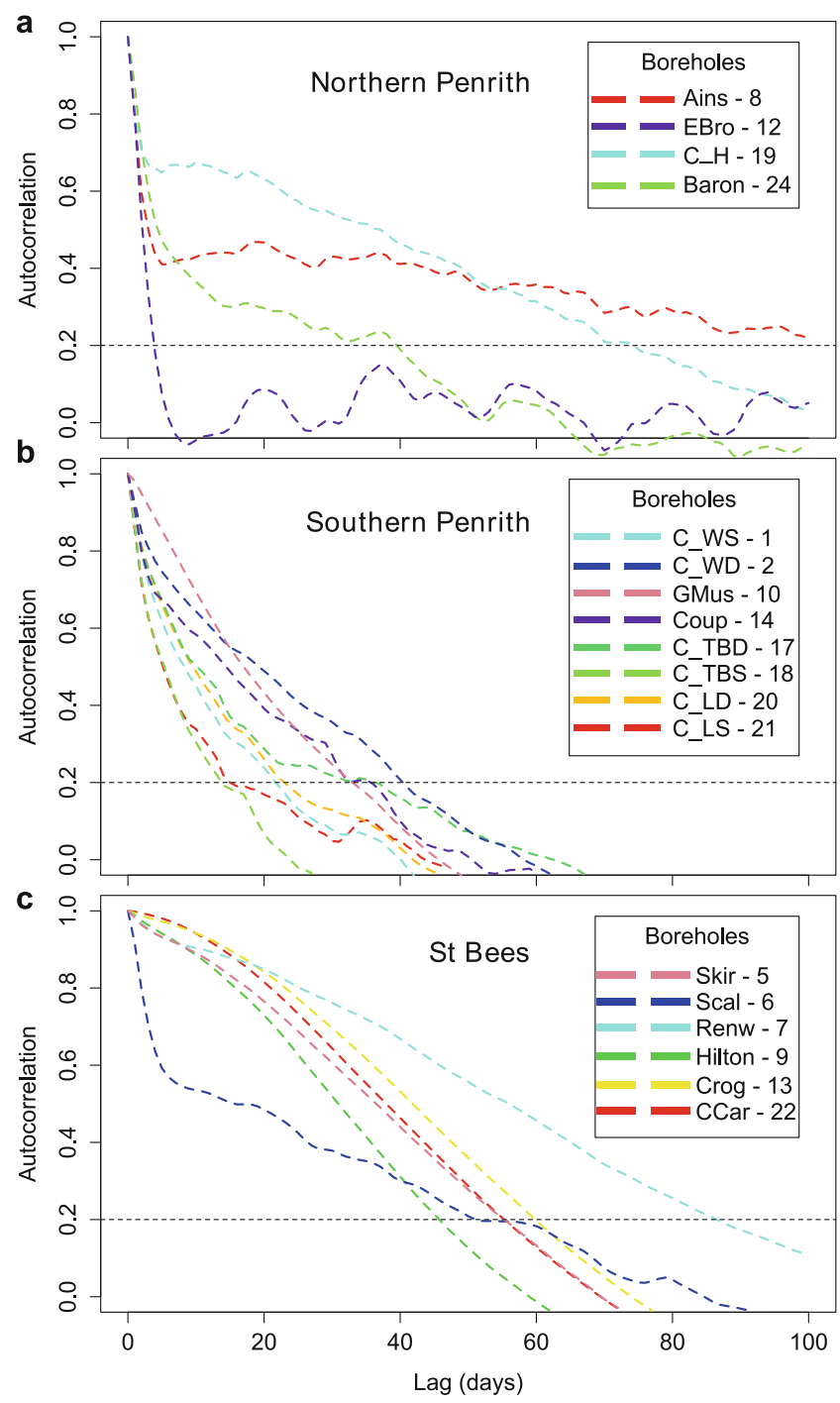

Fig. 8 Correlograms showing the autocorrelation of the remainders time series for different lags. Three groups are formed, according to the type of bedrock: a northern Penrith, b southern Penrith and $\mathbf{c}$ St Bees

paths. In this case, the slope is initially higher and slightly attenuates after approximately 20 days. Borehole No. 10 has a slightly lower slope during the first days. The other boreholes are shallow and are situated very close to streams: River Leith in the Cliburn region, and the Coupland Beck for borehole No. 14. An effective connection with these surface streams can explain in part the initially very steep slope of the correlograms. The northern Penrith boreholes are characterized by correlograms showing an extremely steep slope during the first 4-5 days, followed by a relative stabilization except for borehole No. 12, which attains a null autocorrelation at 6 days. Daily variations were observed on the remainder components (for example borehole No. 8, in Fig. 5a). Such very short-term variations producing a very steep slope in the correlogram could be related to the low porosity of the silicified parts in the northern Penrith Sandstone. 


\section{Conclusions}

The daily groundwater level response in the PermoTriassic sandstone aquifers in the Eden Valley has been studied using the STL time-series decomposition technique. The results of the decomposition were analysed visually and then enhanced by examining the variance ratio, time-series hierarchical clustering and correlation analysis. Differences and similarities in terms of decomposition patterns were explained using the physical and hydrogeological information associated with each borehole. A better understanding of both temporal and spatial influences on groundwater flow has been developed.

The boreholes situated within the St Bees Sandstone generally display hydrographs characterized by a well-defined seasonality whereas the time series from the boreholes in the Penrith Sandstone are more influenced by a long-term trend. The variation in hydrograph behaviour can be explained in terms of differences in aquifer properties and vertical and horizontal heterogeneities. The Penrith Sandstone tends to exhibit significant vertical and horizontal heterogeneity in terms of cementation and grain size as opposed to the St Bees Sandstone which is more homogeneous and tends to act as one aquifer unit. This general distinction is particularly noticeable when looking at the results of the time-series cluster analysis.

The STL decomposition results show a range of distinct patterns within the Penrith Sandstone itself, which underscores the highly heterogeneous character of the Penrith Sandstone both vertically and horizontally. The boreholes characterized by the strongest trend components $(8,12,19$, 24) are located in the northern part of the outcrop which is known to contain silicified beds that could impede the response to localized recharge. On the other hand, the greater relative variance of the seasonality $(40 \%)$ exhibited by borehole 10 and, to a lesser extent, borehole 14, which are both situated in the southern Penrith Sandstone, could be explained by the presence of potentially fractured and weathered carbonate breccias of the Brockram. The cluster analysis confirms the differentiation of these "extreme" groups within the Penrith Sandstone.

Examining the trend shows a general pattern for all boreholes; that of a lower groundwater head during 2004-2006 as well as in 2010-2012. These two events, which are likely to be linked with severe droughts in the UK, are interspersed with higher than average groundwater levels related to the recovery of groundwater levels in between these two droughts.

The network of paired boreholes (shallow 1, 18 and 21; deeper 2, 17 and 20) demonstrates the differences in response associated with the depth of the borehole, indicating potential vertical heterogeneities in the Penrith Sandstone. Moreover, the significance of the remainder signal, especially for the shallower boreholes (boreholes 1,18 and 21) situated very close to streams, emphasize the influence of stream stage via river-aquifer interaction on the hydrograph response. The influence of the variation of stream flow on the shallow boreholes is confirmed by the cross-correlation of the remainder with the rainfall and river flow.

The remainders (de-trended and de-seasonalized time series) were further analysed by examining and comparing their autocorrelation within three main groups: northern and southern Penrith and St Bees. The northern Penrith boreholes correlograms initially exhibit extremely steep slope followed by a relative stabilization. Southern Penrith correlograms display a steeper slope and shorter de-correlation times, which correspond to a lower memory aquifer system characterized by a higher heterogeneity and potentially the presence of more rapid flow paths. The St Bees boreholes remainder correlograms consistently exhibit a slightly decreasing slope and autocorrelation values higher than 0.2 over a relatively long time, indicating a strong memory effect and a rather homogeneous system characterized by significant groundwater storage.

By applying the STL method on the Eden catchment, its suitability as a first step in providing a quantified analysis of groundwater hydrographs is demonstrated. The improved characterisation of the response and of the parameters that influence this response can assist when addressing management issues, demonstrating the importance of the geological heterogeneities at different scales (between aquifer units or within aquifer units) in inducing variable responses to recharge and memory effects. These should be taken into account when addressing problems such as pollutant transfer or the assessment of climate change impact on groundwater flow. The understanding of surface water and groundwater across the catchment could be used to assess the impact that human activities on one part of the system have on another (whether river depletion induced by groundwater abstraction or aquifer contamination by surface water). Finally, the STL methodology can be successfully used as a preliminary analysis to help build or refine a general conceptual model of the groundwater flow within aquifers. The improved understanding of the spatial heterogeneity resulting from the STL decomposition for each borehole can be used to develop numerical groundwater flow models.

Acknowledgements This work has been funded by the UK's Natural Environment Research Council (NERC) under grant NE/I006591/1. The authors are grateful for the daily groundwater and river flow data supplied by the Environment Agency and comments on the hydrogeology were provided by Simon Gebbet. The work is published with the permission of the executive director, BGS (NERC). 
Open Access This article is distributed under the terms of the Creative Commons Attribution 4.0 International License (http:// creativecommons.org/licenses/by/4.0/), which permits unrestricted use, distribution, and reproduction in any medium, provided you give appropriate credit to the original author(s) and the source, provide a link to the Creative Commons license, and indicate if changes were made.

\section{References}

Allen DJ, Bloomfield JP, Robinson VK, et al (1997) The physical properties of major aquifers in England and Wales. WD/97/034, BGS, Keyworth, UK, 312 pp

Balazs GH, Chaloupka M (2004) Thirty-year recovery trend in the once depleted Hawaiian green sea turtle stock. Biol Conserv 117:491498. doi:10.1016/j.biocon.2003.08.008

Benavente J, Pulido-Bosch A (1985) Application of correlation and spectral procedures to the study of discharge in a karstic system (eastern Spain). Congress Int. Hydrogeol. Karst, Ankara, July 1985, IAHS Publ. 161, IAHS, Wallingford, UK, pp 67-75

Bloomfield JP, Marchant BP (2013) Analysis of groundwater drought building on the standardised precipitation index approach. Hydrol Earth Syst Sci 17:4769-4787. doi:10.5194/hess-17-4769-2013

Bouchaou L, Mangin A, Chauve P (2002) Turbidity mechanism of water from a karstic spring: example of the Ain Asserdoune spring (Beni Mellal Atlas, Morocco). J Hydrol 265:34-42. doi:10.1016/S00221694(02)00098-7

Box GEP, Jenkins GM, Reinsel GC (2008) Time series analysis: forecasting and control, 4th edn. Wiley, Englewood Cliffs, NJ

Butcher AS, Lawrence AR, Jackson C et al (2003) Investigation of rising nitrate concentrations in groundwater in the Eden Valley: Phase I project scoping study. National Groundwater and Contaminated Land Centre, Environment Agency, Solihull, UK

Butcher A, Lawrence A, Jackson C et al (2006) Investigating rising nitrate concentrations in groundwater in the Permo-Triassic aquifer, Eden Valley, Cumbria, UK. Geol Soc Lond Spec Publ 263:285-296. doi:10.1144/GSL.SP.2006.263.01.16

Carslaw DC (2005) On the changing seasonal cycles and trends of ozone at Mace Head, Ireland. Atmos Chem Phys 5:3441-3450

Chae G-T, Yun S-T, Kim D-S et al (2010) Time-series analysis of three years of groundwater level data (Seoul, South Korea) to characterize urban groundwater recharge. Q J Eng Geol Hydrogeol 43:117-127. doi:10.1144/1470-9236/07-056

Chaloupka M (2001) Historical trends, seasonality and spatial synchrony in green sea turtle egg production. Biol Conserv 101:263-279. doi: 10.1016/S0006-3207(00)00199-3

Chandler R, Scott M (2011) Statistical methods for trend detection and analysis in the environmental sciences. Statistics in practice, 1 st edn. Wiley, Chichester, UK

Cleveland WS (1979) Robust locally weighted regression and smoothing scatterplots. J Am Stat Assoc 74:829-836. doi:10.1080/01621459. 1979.10481038

Cleveland WS, Devlin SJ (1988) Locally weighted regression: an approach to regression analysis by local fitting. J Am Stat Assoc 83: 596-610. doi:10.1080/01621459.1988.10478639

Cleveland RB, Cleveland WS, McRae JE, Terpenning I (1990) STL: a seasonal-trend decomposition procedure based on loess. J Off Stat 6: 3-73

Delbart C, Valdes D, Barbecot F et al (2014) Temporal variability of karst aquifer response time established by the sliding-windows cross-correlation method. J Hydrol 511:580-588. doi:10.1016/j.jhydrol. 2014.02.008
Di Lazzaro M, Zarlenga A, Volpi E (2015) Hydrological effects of withincatchment heterogeneity of drainage density. Adv Water Resour 76: $157-167$

Esterby SR (1993) Trend analysis methods for environmental data. Environmetrics 4:459-481. doi:10.1002/env.3170040407

Fiorillo F, Doglioni A (2010) The relation between karst spring discharge and rainfall by cross-correlation analysis (Campania, southern Italy). Hydrogeol J 18(8):1881-95. doi:10.1007/s10040-010-0666-1

Ford DC, Williams PW (2007) Karst hydrogeology and geomorphology. Wiley, Chichester, UK

Hannah DM, Smith BPG, Gurnell AM, McGregor GR (2000) An approach to hydrograph classification. Hydrol Process 14:317-338. doi:10.1002/(SICI)1099-1085(20000215)14:2<317::AIDHYP929>3.0.CO;2-T

Hughes RA (2003a) Carboniferous rocks and Quaternary deposits of the Appleby district (part of Sheet 30, England and Wales). British Geological Survey, Keyworth, UK

Hughes RA (2003b) Permian and Triassic rocks of the Appleby district (part of Sheet 30, England and Wales). British Geological Survey, Keyworth, UK

Hulme PJ, Jackson CR, Atkins JK et al (2012) A rapid model for estimating the depletion in river flows due to groundwater abstraction. Geol Soc Lond Spec Publ 364:289-302. doi:10.1144/SP364.18

Keogh E, Pazzani M (2001) Derivative Dynamic Time Warping. Proc. 2001 SIAM Int. Conf. Data Min., April 2001, Society for Industrial and Applied Mathematics, Chicago, pp 1-11

Lafare AEA, Hughes AG, Peach DW (2014) Eden Valley observation boreholes: hydrogeological framework and groundwater level time series analysis. OR/14/041, 14 pp. http://nora.nerc.ac.uk/508772. Accessed 29 July 2015

Larocque M, Mangin A, Razack M, Banton O (1998) Contribution of correlation and spectral analyses to the regional study of a large karst aquifer (Charente, France). J Hydrol 205:217-231

Lee J-Y, Lee K-K (2000) Use of hydrologic time series data for identification of recharge mechanism in a fractured bedrock aquifer system. J Hydrol 229:190-201. doi:10.1016/S0022-1694(00)00158-X

Leedal D, Weerts AH, Smith PJ, Beven KJ (2013) Application of databased mechanistic modelling for flood forecasting at multiple locations in the Eden catchment in the National Flood Forecasting System (England and Wales). Hydrol Earth Syst Sci 17:177-185. doi:10.5194/hess-17-177-2013

Mangin A (1984) Pour une meilleure connaissance des systèmes hydrologiques à partir des analyses corrélatoire et spectrale [For a better understanding of hydrological systems from correlation and spectral analysis]. J Hydrol 67:25-43. doi:10.1016/0022-1694(84) 90230-0

Marsh T (2007) The 2004-2006 drought in southern Britain. Weather 62(7):191-96. doi:10.1002/wea.99

Marsh TJ, Parry S, Kendon MC, Hannaford J (2013) The 2010-12 drought and subsequent extensive flooding: a remarkable hydrological transformation. Centre for Ecology and Hydrology, Wallingford, UK

Mayes WM, Walsh CL, Bathurst JC et al (2006) Monitoring a flood event in a densely instrumented catchment, the Upper Eden, Cumbria, UK. Water Environ J 20:217-226. doi:10.1111/j.1747-6593.2005. 00006.x

Metcalfe AV, Cowpertwait PSP (2009) Introductory time series with R. Springer New York

Millward D, McCormac M, Hughes RA et al (2003) Geology of the Appleby district: a brief explanation of the geological map Sheet 30 Appleby. British Geological Survey, Keyworth, UK

Padilla A, Pulido-Bosch A (1995) Study of hydrographs of karstic aquifers by means of correlation and cross-spectral analysis. J Hydrol 168:73-89. doi:10.1016/0022-1694(94)02648-U

Rademacher LK, Clark JF, Hudson GB (2002) Temporal changes in stable isotope composition of spring waters: implications for recent 
changes in climate and atmospheric circulation. Geology 30:139 142. doi:10.1130/0091-7613(2002)030<0139:TCISIC >2.0.CO;2

Seymour K, Atkins J, Handoo A et al (2008) Investigation into groundwater-surface water interactions and the hydro-ecological implications of two groundwater abstractions in the River Leith catchment, a sandstone-dominated system in the Eden Valley, Cumbria: a study undertaken for the Review of Consents under the Habitats Directive, Environment Agency, Rotherham, UK

Shamsudduha M, Chandler RE, Taylor RG, Ahmed KM (2009) Recent trends in groundwater levels in a highly seasonal hydrological system: the Ganges-Brahmaputra-Meghna Delta. Hydrol Earth Syst Sci 13:2373-2385. doi:10.5194/hess-13-2373-2009

Stone P, Millward D, Young B et al (2010) British regional geology: Northern England, 5th edn. British Geological Survey, Keyworth, UK

Taylor CJ, Alley WM (2002) Ground-water-level monitoring and the importance of long-term water-level data. US Geological Survey, Reston, UK

Upton KA, Jackson CR (2011) Simulation of the spatio-temporal extent of groundwater flooding using statistical methods of hydrograph classification and lumped parameter models. Hydrol Process 25: 1949-1963. doi:10.1002/hyp.7951

Wang L, Stuart ME, Bloomfield JP et al (2012) Prediction of the arrival of peak nitrate concentrations at the water table at the regional scale in Great Britain. Hydrol Process 26:226-239. doi:10.1002/hyp.8164

Wang L, Butcher AS, Stuart ME et al (2013) The nitrate time bomb: a numerical way to investigate nitrate storage and lag time in the unsaturated zone. Environ Geochem Health 35:667-681. doi:10. 1007/s10653-013-9550-y

Waugh B (1970) Petrology, provenance and silica diagenesis of the Penrith Sandstone (Lower Permian) of northwest England. J Sediment Res 40:1226-1240

Winter TC, Mallory SE, Allen TR, Rosenberry DO (2000) The use of principal component analysis for interpreting ground water hydrographs. Ground Water 38:234-246. doi:10.1111/j.1745-6584. 2000.tb00335.x

Zhao Y (2012) R and data mining: examples and case studies. Academic, San Diego 